\title{
Review
}

\section{Development of Functional Foods in the Philippines}

\author{
Evelyn Mae Tecson-MendozA*
}

Institute of Plant Breeding, Crop Science Cluster, College of Agriculture, University of the Philippines Los Baños, College, Laguna 4031, Philipppines

Received February 15, 2007; Accepted March 27, 2007

\begin{abstract}
Filipinos have traditionally recognized that some foods have benefits beyond nutrition although the term "functional foods" is new to them. Various studies show the nutritional and medical benefits of common Philippine foods. This paper reviews the functional attributes of selected traditional Philippine foods such as rice (Oryza sativa L.), coconut (Cocos nucifera L.), legumes [mungbean [Vigna radiata $\mathrm{L}$. Wilczek]) and indigenous legumes], selected native vegetables (Momordica charantia and Moringa olifeira), root crops (sweetpotato (Ipomoea batatas), greater yam (Dioscorea alata) and taro (Colocasia esculenta)] and fruits [mango (Mangifera indica), papaya (Carica papaya), banana (Musa sp.) and pineapple (Ananas comosus)]. Processed food products with functional attributes include nata de coco and achara or pickled grated papaya. Germination and fermentation processes have been shown to improve the health benefits of some foods. Increasingly becoming popular are food products promoted with health benefits such as fermented milk drinks, yoghurt with lactobacillus, spirulina cereal, ganoderma coffee, milk with Bifidobacteria, etc. Evaluation of food products that qualify as functional foods on a scientific basis is done under the existing regulations of the Bureau of Food and Drugs of the Philippines Department of Health. Concerned government agencies have been involved in technical consultation meetings in the Asian region aimed at harmonizing the standards for regulating functional foods in the region. From this review, more studies are recommended on the functional attributes of Philippine traditional foods and newly developed ones, to establish their health benefits and determine the recommended amount and frequency of intake needed to obtain the benefits. An information campaign on functional foods among consumers and the general public should be conducted to enable them to en joy the benefits of food "beyond nutrition."
\end{abstract}

Keywords: functional foods, Philippines, phytochemicals, antioxidants

\section{Introduction}

The term "functional foods" is new in the Philippines. However, like their neighbors, Filipinos have traditionally recognized that some foods have benefits beyond nutrition. Several professional and international health organizations have defined functional foods that include conventional whole foods, enhanced or enriched foods, as foods that provide health benefits or beneficial physiological effects other than nutrition (IFIC, 1998; ILSI, 1999). However, in some countries like the United States, functional food encompasses whole foods and dietary supplements under the category of nutraceuticals.

Japan has led in the establishment of government regulations, researches and commercialization of functional foods called "Foshu" products. Foshu stands for "Foods for Specified Health Use" (FOSHU), a policy created by the Japanese Ministry of Health and Welfare in 1991, the first in the world for the legal approval of the commercialization of functional foods (Arai et al., 2001). In the United

* To whom correspondence should be addressed.

E-mail: emtmendoza@nast.ph; emtmphil@yahoo.com
States, the US Food and Drug Administration (FDA), regulates functional foods under the Federal Food, Drug and Cosmetic Act of 1938, and the scientifically sound approach to labeling and marketing is regulated under the Nutrition Labeling and Education Act of 1990 (ADA, 2004). The Philippines presently regulates all foods including functional foods under its Food and Drug, and Cosmetics Act (RA3720).

This paper focuses on (1) the functional attributes of selected traditional Philippine foods, (2) processed functional food products, (3) status of regulation, (4) recommendations.

\section{Traditional Foods as Functional Foods}

Rice Rice, the staple food of most Filipinos, has functional qualities due to its dietary fiber, lipid and nature of starch. The functional attributes of rice have been reviewed extensively before (Moldenhauer et al., 1998; Obanni et al., 1998). The book "Rice Chemistry and Quality" by B.O. Juliano (2003) serves as an excellent source book on the topic.

Milling of rice results in the removal of bran resulting 
Table 1. Summary of Philippine traditional foods and their potential functional attributes.

\begin{tabular}{|l|l|l|}
\hline Foods & Functional components & Potential benefits \\
\hline Rice (Oryza sativa L.) & $\begin{array}{l}\text { Dietary fiber } \\
\text { Lipids } \\
\text { Oryzanol, tocopherols, etc, } \\
\text { phytic acid } \\
\text { B-vitamins in the bran }\end{array}$ & $\begin{array}{l}\text { Control of blood sugar } \\
\text { Antioxidants; Anti cancer }\end{array}$ \\
Anti-beri beri
\end{tabular}

in large losses of minerals $(1.0-1.5$ to $0.3-0.8 \%)$, dietary fiber, especially insoluble fiber (2.0 to $0.5 \%$ wet basis) and phenolics (0.62-0.7\% catechin (Juliano and Bechtel, 1985). Rice bran is rich in the B-vitamins, Vitamin E $(5.5 \mathrm{mg} / 100$ g), lipids, minerals and phosphatides (Gregorio et al., 2000). The antioxidants in rice bran include oryzanol, the tocopherols and tocotrienols. Oryzanol and phytate are commercially extracted from rice bran and utilized as nutraceuticals. An extract from rice bran called TikiTiki is rich in thiamine and has been traditionally used to cure beriberi and is a popular vitamin drop for infants. The consumption of brown rice is now widely promoted. The Philippines also boasts of several pigmented rice varieties (red, violet and black) which have high antioxidant activities and dietary fiber. The purple pigmented Perurutong brown rice has $0.62 \%$ catechin compared to the milled counterpart of only 0.07\% (Eggum et al., 1981). Some of the potential benefits of the functional components in rice are: control of blood sugar due to the relatively high dietary fiber, the lowering of cholesterol due to the lipids, the high antioxidant and anticancer potential due to oryzanol, tocopherols and phytic acid in the bran, and antiberi-beri because of the high vitamin $\mathrm{B}$ content of the bran.

Legumes Mungbean is a popular legume in the Philippines and in many Asian countries, and is used as grain or sprout. The mungbean grain contains $17-26 \%$ protein and is considered a major source of protein in developing countries. Mungbean seeds are also a good source of minerals and vitamins. Mungbean starch is the material used in the manufacture of the translucent noodle called "sotanghon."

Mungbean flour has 30\% fiber, (4\% soluble and 26\% insoluble) and has a low glycemic index. A four week study involving 10 females with type 2 diabetes and whose ages ranged from 32-60 yr fed with diets of high glycemic diet of white rice and low glycemic diet of mungbean noodles showed that ingestion of mungbean noodles without increasing fiber intake improves diabetic control (Komindar et al., 2001). Trinidad et al. (2005) also showed that the glycemic index (GI) of mungbean was statistically similar in normal and diabetic subjects.

Sprouts of mungbean are a popular form of vegetable for Filipinos. Sprouting results in increased the ascorbic acid content (Prudente and Mabesa, 1981). Further, sprouting of mungbean, combined with biological, chemical and physical stress, has been shown to stimulate production of phytochemicals relevant to chemoprevention including phenolic content, G6PDH and guiacol peroxidase enzyme activities accompanied by an increase in proline content (McCue and Shetty, 2002). In addition, antimicrobial activities were shown to be stimulated in dark germinated mungbean sprouts in response to peptide and phytochemical elicitors (Randhir et al., 2004). The laboratory of Prof. Shetty at the University of Massachusetts has extensively studied this concept of elicitor induced stimulation of production of phytochemicals with chemopreventive potential in germinating seeds of soybean, peas, fava bean, mungbean and fenugreek (Smith-Schneider, 2006) which has become the basis for the development of a technology platform.

Studies on factors affecting the nutritional quality and 
acceptability of mungbean have been reviewed by Mendoza et al. (1988). We have also studied the major storage protein of mungbean vicilin (Tecson-Mendoza et al., 2001), cloned and characterized its gene and expressed it in Escherichia coli (Bernardo et al., 2002) in cooperation with the laboratory of Professor Shigeru Utsumi of Kyoto University. We have investigated the functional properties of the recombinant and native vicilin of mungbean (Garcia et al., 2006) and determined the structure of the recombinant vicilin by X-ray crystallography (Itoh $e t$ al., 2006). We are presently conducting a study to attempt to improve further the nutritional and functional quality of mungbean protein by engineering methionine and sulfhydryl in the vicilin.

Like other tropical countries, the Philippines has rich genetic resources which include several indigenous food legumes, namely, jackbean (Canavalia ensiformis), swordbean (Canavalia gladiata), sam-samping (Clitoria ternatea), batao or hyacinth bean (Dolichos lablab), sabawel (Mucuna pruriens or $M$. conchinensis), rice bean (Vigna umbellata), lima bean (Phaseolus lunatus) and pigeon pea (Cajanus cajan). We have conducted studies on the biochemical and nutritional qualities of these legumes, which had been published in various journals and summarized in a monograph (Tecson-Mendoza et al., 2003). Various plant parts of these legumes such as the immature pods, the mature seeds and immature leaves are cooked and utilized as foods in different parts of the country. However, only hyacinth bean, lima bean, pigeon pea and rice bean are available in the market or grown in the backyard for home consumption. In addition to their uses as foods, almost all of these legumes have medicinal values such as antiallergenic effects, hepatoprotective activity, anti-diabetic, anti-microbial, anticancer, etc (as summarized in the monograph) using the edible and non-edible parts of the plant. More studies should be conducted to determine functional attributes of these indigenous legumes toward their enhanced utilization.

Coconut Food products from coconut are varied: fresh coconut water, fresh coconut meat, coconut milk, virgin coconut oil which is obtained from the coconut milk or expelled from clean desiccated coconut, copra oil refined to become vegetable oil, coconut flour and coconut protein. Coconut water or the liquid endosperm is a nutritious, refreshing and healthful water, an excellent rehydration medium, and has been used to prevent formation of stones in the urinary tract. A comprehensive review of the health benefits of coconut oil is available (Enig, 1999).

The gata or coconut meat extract also called coconut milk contains proteins, oil, and other phytochemicals. This gata is widely used in cooking with vegetables and meat. Dessicated coconut is about $69 \%$ oil while gata is $24 \%$ oil. Coconut oil has been shown to have antimicrobial activity against include bacteria, yeast, fungi, and enveloped viruses (Kabara, 1978). The major fatty acid of coconut oil, lauric acid, has antimicrobial activity and its monoglyceride has even higher activity.

Virgin coconut oil's export market has increased tremendously in the past two years, from $177 \mathrm{MT}$ in 2004 to
340 MT during the first half of 2005 with the US taking more than $97 \%$ of said export (PDI, 2005). VCO has been cited for its health benefits. We have compared the physicochemical properties of VCOs produced by different processes (extraction of the fresh meat to get the coconut milk which is heated at $40^{\circ} \mathrm{C}$ to separate the oil, expelling of oil from clean desiccated coconut meat and freeze and thaw of coconut milk to separate the oil (Dia et al., 2005). Our results showed that there were some differences in the physicochemical properties of the VCOs produced by different methods but the differences were not large enough to significantly affect the overall quality of the VCO. Moreover, the levels of the physical and chemical qualities were still within the Codex standards for coconut oil and the Philippine standards for VCO. From this study, the total phenolic content of the VCO samples ranged from 23 to $91 \mathrm{mg}$ catechin equivalent/kg, much lower than the values of 318,1326 and $1092 \mathrm{mg}$ catechin equivalent/kg for olive oil, grape wine and coconut meat (Dia et al., 2005). The antioxidant potential levels of the VCO samples were found to be as high or up to twice as high as the control $\alpha$-tocopherol (Dia et al., 2005). A 45day feeding study of Sprague-Dawley rats with virgin coconut oil compared with copra oil showed the reduction of total cholesterol, triglycerides, phospholipids, LDL, and VLDL cholesterol levels and increased HDL cholesterol in serum and tissues (Nevin and Rajonohan, 2004). The polyphenolic fraction of virgin coconut oil also prevented in vitro LDL oxidation with reduced carbonyl formation.

Coconut solid endosperm consists of $8 \%$ protein which is retained in the residue after expelling the oil. The effects of coconut protein on the lipid metabolism of rats fed with a high fat cholesterol containing diet showed that those fed coconut protein had significantly lower levels of total cholesterol, LDL + VLDL cholesterol, triglycerides and phospholipids in the serum and higher levels of serum HDL cholesterol (Salil and Rajamohan, 2001). This study demonstrated that coconut protein is able to reduce hyperlipidemia and peroxidative effect induced by high fat cholesterol containing diet.

Another by-product of the coconut industry is coconut flakes or flour which consists of $60 \%$ dietary fiber $(56 \%$ insoluble and $4 \%$ soluble). Bakery products supplemented with increasing levels of coconut flour were fed to normal and diabetic subjects. The results showed that the glycemic index of the foods supplemented with coconut flour decreased with increasing levels of coconut flour (Table 2) (Trinidad et al., 2003). In a separate study, the effects of feeding coconut flakes or flour to human subjects with moderately raised serum cholesterol (from 259 to $283 \mathrm{mg}$ / dL) showed that $15 \%$ and $25 \%$ coconut flakes reduced serum total and LDL cholesterol and serum triglycerides of human subjects with moderately raised serum cholesterol.

Because of its high medium chain fatty acid content, coconut oil is easily absorbed and digested and is used as a therapeutic diet for convalescing patients.

Native Vegetables Moringa oleifera or malunggay is a tree which can grow up to ten feet and its every part can 
Table 2. Dietary fiber content and glycemic index of coconut flour, legumes and root crops.

\begin{tabular}{|c|c|c|c|c|c|}
\hline \multirow[t]{2}{*}{ Sample } & \multicolumn{3}{|c|}{ Dietary fiber $(\mathrm{g} / 100 \mathrm{~g})$} & \multicolumn{2}{|c|}{ Glycemic index } \\
\hline & Total & Insoluble & Soluble & Normal & Diabetic \\
\hline Coconut flour ${ }^{\mathrm{a}}$ & 57 & 54 & 3 & 54.75 & 59.98 \\
\hline Root crops ${ }^{b}$ : & & & & & \\
\hline $\begin{array}{l}\text { Greater yam } \\
\text { (Dioscorea alata) }\end{array}$ & 11 & 8 & 3 & 41 & 33 \\
\hline $\begin{array}{l}\text { Sweetpotato } \\
\text { (Ipomoea batatas) }\end{array}$ & 7 & 3 & 4 & 48 & 48 \\
\hline $\begin{array}{l}\text { Cassava } \\
\text { (Manihot esculenta) }\end{array}$ & 3 & 2 & 1 & 53 & 52 \\
\hline $\begin{array}{l}\text { Taro (gabi) } \\
\text { (Colocasia esculenta) }\end{array}$ & 12 & 8 & 4 & 46 & 46 \\
\hline Legumes $^{\mathrm{b}}$ : & & & & & \\
\hline $\begin{array}{l}\text { Mungbean } \\
\text { (Vigna radiata) }\end{array}$ & 31 & 27 & 4 & 14.3 & 10.5 \\
\hline $\begin{array}{l}\text { Lima bean } \\
\text { (Phaseolus lunatus) }\end{array}$ & 20 & 17 & 3 & nd & nd \\
\hline $\begin{array}{l}\text { Pigeon Pea } \\
\text { (Cajanus cajan) }\end{array}$ & 20 & 18 & 2 & 8.5 & 6.3 \\
\hline $\begin{array}{l}\text { Pole sitao } \\
\text { (Vigna sinensis) }\end{array}$ & 34 & 30 & 4 & 8.5 & 5.7 \\
\hline
\end{tabular}

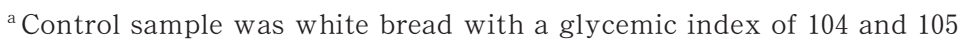
for normal and diabetic subjects, respectively.

The glycemic index for coconut flour was obtained from the average of four test samples with 200 and $250 \mathrm{~g} / \mathrm{kg}$ coconut flour (Trinidad et al., 2003).

${ }^{\mathrm{b}}$ From Trinidad (2005).

be utilized as a health food. Malunggay is native to India, Arabia and possibly Africa and the East Indies. However, it is now widely cultivated and indigenized in tropical Africa, tropical America, India, Sri Lanka, Malaysia and the Philippines. Its leaves are popularly used as vegetable in various dishes. The nutrient composition of $100 \mathrm{~g}$ of cooked malunggay leaves is as follows: $3.1 \mathrm{~g}$ protein, $0.6 \mathrm{~g}$ fiber, $96 \mathrm{mg}$ calcium, $29 \mathrm{mg}$ phosphorus, $1.7 \mathrm{mg}$ iron, $2,820 \mathrm{mg} \beta$-carotene, $0.07 \mathrm{mg}$ thiamin, $0.14 \mathrm{mg}$ riboflavin, $1.1 \mathrm{mg}$ niacin, and $53 \mathrm{mg}$ ascorbic acid or vitamin $\mathrm{C}$ (Marero, 2006). Malunggay has high antioxidant activity (twice that of the control Vitamin E) due to its high Vitamin A, B and C content and niaziminin which has also been shown to have anti-tumor potential. Very strong, novel hypotensive principles O-[2'-hydroxy-3'-(2" -heptenyloxy)]-propyl undecanoate (1) and O-ethyl-4-[(alpha-L-rhamnosyloxy)-benzyl] carbamate (2) along with the known substances methyl p-hydroxybenzoate (3) and betasitosterol were isolated in malunggay (Faizi et al., 1998). It has good quality protein which has an amino acid pattern higher than the FAO standard. Its oil, called Benoil, is odorless, does not become rancid and is edible.

The extract of Moringa olifeira has been shown to significantly decrease hepatic marker enzymes and lipid peroxidation while increasing the level of antioxidants in rats which had been induced to have high lipid peroxidation by using antitubercular drugs (Ashok Kumar and Pari, 2003). Another study showed the chemoprotective potential of Moringa olifeira against chemical carcinogenesis as shown by its effects on hepatic carcinogen metabolizing enzymes and skin papillomagenesis in mice (Bharali et al., 2003).

Momordica charantia, bitter gourd or ampalaya, is another very popular local vegetable which has established beneficial health effects. The fruit is used as vegetable and has anti-diabetic effects and high antioxidant poten- tial. It has been used as folk remedy for diabetes in several Asian countries.

Oral administration of the seed extract of $M$. charantia showed significant decrease in fasting blood glucose, hydroperoxides and an increase in enzymes involved in antioxidant production in the liver and kidney of diabetic rats (Sathishsekar and Subramanian, 2005). Extracts of $M$. charantia have also been shown to be effective in scavenging nitric oxide and thus could be a novel therapeutic agent for the regulation of pathological conditions brought about by excessive levels of NO (Jagetia and Baliga, 2004). The anticancer potential of $M$. charantia has also been shown against benzopyrene-induced forestomach papillomagenesis in mice (Deep et al., 2004). Garcia et al. (2004) showed that edible portions of native vegetables such as eggplant, bitter melon, horseradish tree leaves, string long beans leaves, etc., had relatively high levels of antioxidants.

Root Crops Several commonly utilized root crops in the Philippines such as sweetpotato (Ipomoea batatas), taro or gabi (Colocasia esculenta), greater yam or ube (Dioscorea alata) and cassava (Manihot esculenta) have excellent dietary fiber content and are low glycemic index foods. Table 2 shows the dietary fiber contents and the glycemic index of the root crop samples in normal and diabetic subjects (Trinidad et al., 2005). The dietary fiber contents of the root crops ranged from 3 to $12 \mathrm{~g} / 100 \mathrm{~g}$ for cassava and taro, respectively. Greater yam had the highest percent of insoluble fiber (73\%) and sweet potato the lowest $(43 \%)$. With the four root crops, the glycemic index in the diabetic subjects was the same or lower (Table 2) indicating the ability of the dietary fiber of such food to control the release of glucose into the blood and, thus, helps in the proper management of diabetes mellitus.

We have studied the antioxidant potential of several varieties of greater yam, sweet potato and taro and ob- 
Table 3. Nutrient composition of raw edible portions of tropical fruits (mango, papaya, banana and pineapple).

\begin{tabular}{|c|c|c|c|c|c|}
\hline Nutrient & Unit & Mangos & Papayas $^{1}$ & Bananas & Pineapple $^{2}$ \\
\hline \multicolumn{6}{|l|}{ Proximates } \\
\hline Water & $\mathrm{g}$ & 81.71 & 88.83 & 74.91 & 86.46 \\
\hline Energy & kcal & 65 & 39 & 89 & 48 \\
\hline Protein & $\mathrm{g}$ & 0.51 & 0.61 & 1.09 & 0.54 \\
\hline $\begin{array}{l}\text { To } \\
\text { tal lipid (fat) }\end{array}$ & $\mathrm{g}$ & 0.27 & 0.14 & 0.33 & 0.12 \\
\hline Ash & $\mathrm{g}$ & 0.50 & 0.61 & 12 & 0.24 \\
\hline Carbohydrate, by difference & $\mathrm{g}$ & 17.00 & 9.81 & 0 & 12.63 \\
\hline Fiber, total dietary & $\mathrm{g}$ & 1.80 & 1.8 & 13 & 1.4 \\
\hline Sugars, total & $\mathrm{g}$ & 14.80 & 5.90 & 12.23 & 9.26 \\
\hline Starch & $\mathrm{g}$ & & & 5.38 & \\
\hline \multicolumn{6}{|l|}{ Minerals } \\
\hline Calcium, $\mathrm{Ca}$ & $\mathrm{mg}$ & 10 & 24 & 5 & 13 \\
\hline Iron, $\mathrm{Fe}$ & $\mathrm{mg}$ & 0.13 & 0.10 & 0.26 & 0.28 \\
\hline Magnesium, $\mathrm{Mg}$ & $\mathrm{mg}$ & 9 & 10 & 27 & 12 \\
\hline Phosphorus, $\mathrm{P}$ & $\mathrm{mg}$ & 11 & 5 & 22 & 8 \\
\hline Potassium, K & $\mathrm{mg}$ & 156 & 257 & 358 & 115 \\
\hline Sodium, $\mathrm{Na}$ & $\mathrm{mg}$ & 2 & 3 & 1 & 1 \\
\hline Zinc, $\mathrm{Zn}$ & $\mathrm{mg}$ & 0.04 & 0.07 & 0.15 & 0.10 \\
\hline Copper $\mathrm{Cu}$ & $\mathrm{mg}$ & 0.110 & 0.016 & 0.078 & 0.099 \\
\hline Manganese, $\mathrm{Mn}$ & $\mathrm{mg}$ & 0.027 & 0.011 & 0.270 & 1.177 \\
\hline Selenium, Se & $\mathrm{mc}$ & 0.6 & 0.6 & 1.0 & 0.1 \\
\hline \multicolumn{6}{|l|}{ Vitamins } \\
\hline Vitamin C, ascorbic acid & $\mathrm{mg}$ & 27.7 & 61.8 & 8.7 & 36.2 \\
\hline Thiamin & $\mathrm{mg}$ & & 0.027 & 0.031 & 0.079 \\
\hline Riboflavin & $\mathrm{mg}$ & 0.058 & 0.032 & 0.073 & \\
\hline Niacin & $\mathrm{mg}$ & 0.584 & 0.338 & 0.665 & 0.489 \\
\hline Pantothenic acid & $\mathrm{mg}$ & 0.160 & 0.218 & 0.334 & 0.035 \\
\hline Vitamin B6 & $\mathrm{mg}$ & 0.134 & 0.019 & 0.367 & 0.110 \\
\hline Folate, total & $\mathrm{mcg}$ & 14 & 38 & 20 & 15 \\
\hline Vitamin B12 & $\mathrm{mcg}$ & 0.00 & 0 & 0 & 0 \\
\hline Vitamin A & IU & 765 & 1094 & 0 & 56 \\
\hline Retinol & mcg & 0 & 0 & 0 & 0 \\
\hline $\begin{array}{lll}\begin{array}{l}\text { Vitamin } \\
\text { tocopherol) }\end{array} & \mathrm{E} & \text { (alpha- }\end{array}$ & $\mathrm{mg}$ & 1.12 & 0.73 & 0.10 & 0.02 \\
\hline Vitamin K (Phylloquinone) & $\mathrm{mcg}$ & 4.2 & 2.6 & 0.5 & 0.7 \\
\hline \multicolumn{6}{|l|}{ Others } \\
\hline Caffeine & $\mathrm{mg}$ & 0 & 0 & 0 & 0 \\
\hline Throbromine & $\mathrm{mg}$ & 0 & 0 & 0 & 0 \\
\hline Carotene, beta & $\mathrm{mcg}$ & 445 & 276 & 26 & 34 \\
\hline Carotene, alpha & $\mathrm{mcg}$ & 17 & 0 & 25 & 8 \\
\hline Cryptoxanthine, beta & $\mathrm{mcg}$ & 11 & 761 & 0 & 0 \\
\hline Lycopene & $\mathrm{mcg}$ & 0 & 0 & 0 & 0 \\
\hline Lutein + zeaxanthine & $\mathrm{mcg}$ & 0 & 75 & 22 & 0 \\
\hline
\end{tabular}

Source: USDA National Nutrient Database for Standard Reference, Release 18 (2005).

http://www.nal.usda.gov.fnic/foodcomp/search/index.html (Accessed August 2006).

${ }^{1}$ Based on orange-fleshed papaya.

${ }^{2}$ Values based on data weighted $50 \%$ extra sweet variety, $50 \%$ traditional varieties.

served their antioxidant potential to be similar or even higher than the control BHA and $\alpha$-tocopherol (Mendoza et al., 1994; Lubag et al., 2007).

Fruits The major tropical fruits produced in the Philippines are mango, pineapple, banana and papaya. These are all established to have high contents of some vitamins, minerals and phytochemicals which make their intake beneficial to human health (Table 3). In particular, these fruits are high in potassium, with banana and papaya having the highest content of 358 and $257 \mathrm{mg} \%$. Papayas have very high levels of ascorbic acid $(61.8 \mathrm{mg} \%)$ followed by pineapple $(36.2 \mathrm{mg} \%$ ) and mangos $(27.7 \mathrm{mg} \%)$. The four types of fruits contain the B-vitamins in varying concentrations. The red-or orange-fleshed papayas and mangos are also rich in Vitamin A (1094 and 765 IU, respectively) and beta carotene (276 and $445 \mathrm{mcg} \%$, respectively)(USDA, 2005). Many other tropical fruits such as durian, mangosteen, jackfruit, etc. have become important sources of vitamins, minerals and phytochemicals.
In terms of antioxidant potential, green and ripe mango, and green and ripe papaya exhibit relatively high antioxidant activities but only $30 \%$ of the antioxidant activity of red and white guava (Mahattanatawee, 2006).

Further studies showed that whole mango juice and juice extracts had anticancer activity as shown by their ability to inhibit the cell cycle of HL-60 cells in the G(0)/ $\mathrm{G}$ (1) phase. Whole mango juice was also found effective in reducing the neoplastic transformation of the HL-60 cells (Percival et al., 2006). Mangiferin, a poly phenol from mango, was demonstrated to exert a protective role against isoproterenol (ISPH)-induced mycocardial infarction (MI) in rats through its antioxidative mechanism (Prabhu et al., 2006) as well as radioprotective property by suppressing the effects of free radicals (Jagetia and Venkatesha, 2005).

Banana was reported to be the most effective scavenger of peroxyl radicals among tropical fruits but was the poorest HOCL scavenger (Murcia et al., 2001). However, 
like other tropical and Mediterranean fruits, banana exhibited strong effect on hydrogen peroxide. Banana contains dopamine ranging from $80-560 \mathrm{mg}$ per $100 \mathrm{~g}$ in the peel and 2.5-19 mg per $100 \mathrm{~g}$ in the pulp (Kanazawa and Sakakibara, 2000). Dopamine has stronger antioxidant activity than glutathione or the food additives such as butylated hydroxyanisole and hydroxytoluene (BHA, BHT). Methanolic extracts of banana have also been shown to have ulcer protective effect due to their effect on mucosal glycoproteins, cell proliferation, antioxidant and free radicals (Mohan Kumar et al., 2006).

Pineapple also exhibits strong antioxidant activity but is lower than that of banana and other fruits like cranberry, apple, red grape etc (Sun et al., 2002). Interestingly, mango and pineapple have moderate enhancing effect on Fe absorption (0.031-0.088) from a rice meal while papaya and guava markedly increase Fe absorption (0.126-0.298) (Ballot et al., 1987). Such effect on Fe absorption from a rice meal was found to be correlated with the ascorbic acid content of the fruits tested. This is an important finding as iron intake is a problem especially with women in developing countries.

\section{Processed Food Products}

Nata de coco is a popular dessert and ingredient of refreshments and salads in the Philippines and became very popular in Japan in the 1990s as a health food primarily because of its being a good source of dietary fiber. Nata is produced on an acidic sugar rich medium of coconut water by Acetobacter aceti subsp. xylinum. Several substrates from pineapple, santol, guava, jackfruit, sugarcane and papaya have been found to support the growth of the nata. However, commercial nata from coconut is still the only nata produced most probably because of the greater availability of coconut water as waste by product. Achara or pickled grated unripe papaya is a favorite and popular pickled food consumed by Filipinos with all types of grilled and fried dishes. It is made from grated flesh of green papaya fruits, aged and prepared with garlic, onion, ginger, carrots and red pepper in a sauce consisting of vinegar, salt and sugar. Such a mixture is expected to have a good level of antioxidants and other beneficial phytochemicals.

Processing of fruits or vegetables may further enhance or decrease their nutritional as well as functional properties. Fermented papaya is a major ingredient of a natural Japanese health food called Bio-normalizer which is manufactured in the Philippines. It has been shown to exhibit therapeutic properties against tumor, various enteropathogens and immunodeficiency (Osato et al., 1993, 1995). Studies showed that the product efficiently inhibited formation of oxygen radicals or scavenged superoxide and hydroxyl radicals and increased activities of enzymes involved in antioxidant activity like superoxide dismutase (SOD) (Osato et al., 1993, 1995; Santiago et al., 1993).

Other new functional food products which have been approved for commercial release in the country include yoghurt with lactobacillus, spirulina cereal, ganoderma coffee, milk with Bifidobacteria, and hotdog with inulin.

\section{Status of Regulation of Functional Foods in the Philippines}

Presently, there are no specific regulations for functional foods in the Philippines. Food products that qualify as functional foods are evaluated based on scientific basis under existing regulations of the Bureau of Food and Drugs (BFAD) under the Department of Health. BFAD has also issued several guidelines on probiotics, on the formulation, labeling, technical specifications that will have to be provided for evaluation. The product information and other requirements for applications include: (1) list of ingredients, (b) physical, chemical and microbiology characteristics of the product, (3) presentation of actual sample for sensory evaluation, (4) presentation of sample label in which health or nutritional claims should refer to the functional ingredient or component and not to the finished product, (5) shelf life and methods used to determine such, and (6) brief description of manufacturing process. All health or nutritional claims should be supported by technical scientific reports.

Concerned government agencies have been involved in technical consultation meetings in Asian region toward harmonized standards for regulation of functional foods in the region. Recently, a symposium on functional foods was held in Manila in May 2006, which gathered food scientists and government regulators to discuss the issues on and regulatory needs for functional foods. It was recognized that there is no consensus on the definition or usage of the term functional foods. Some countries include both dietary supplements and conventional foods in their definition of functional foods. Based on statements from BFAD (Alba, 2006), the definition of functional foods that the Philippine government has recommended to be adopted is that of functional foods being conventional foods with nutrients that have potential health benefits or desirable physiological effects and that functional foods should not be confused with food supplements.

\section{Recommendations}

For all the foods described, the amount and frequency needed to take them to obtain their beneficial effects are not known. Many of the indigenous legumes and the native vegetables are utilized as foods and concoctions of various parts have been used to obtain medical benefits (Tecson-Mendoza et al., 2003).

Based on this review, more studies are needed on the functional attributes of traditional foods in the Philippines and newly developed ones to establish their health benefits and the recommended amount and frequency of intake of these functional foods needed to obtain their benefits. The Philippine government should also promote functional foods and support researches to establish the health benefits of traditional and newly developed functional foods. It is also imperative to disseminate information on functional foods to consumers and the general public to enable them to enjoy the health benefits of food. 


\section{References}

ADA (American Dietetic Association) (2004). Position of the American Dietietic Association: Functional foods. J. Am. Diet. Assoc., 104, 814-826.

Alba, O.M. (2006). Regulations on functional foods. Presented during the Symposium on Functional Foods, sponsored by ILSI-Southeast Asia, Manila, Philippines, May 17, 2006.

Arai, S., Osawa, T., Ohigashi, H., Yoshikawa, M., Kaminogawa, S., Watanabe, M., Ogawa, T., Okubo, K., Watanabe, S., Nishino, H., Shinohara, K., Esashi, T. and Hirahara, T. (2002). A mainstay of functional food science in Japan-History, present status, and future outlook. Biosci. Biotechnol. Biochem., 65, 1-13.

Ashok Kumar, N. and Pari, L.(2003). Antioxidant action of Moringa oleifera Lam. (drumstick) against antitubercular drugs induced lipid peroxidation in rats. J. Med. Food, 6, 255259.

Ballot, D., Baynes, R.E., Bothwell, T.H., Gillooly, M., MacFarlane, B.J., MacPhail, A.P., Lyons, G., Derman, D.P., Bezwoda, W.R. and Rorrance, J.D. (1987). The effects of fruit juices and fruits on the absorption of iron from a rice meal. Br. J. Nutr., 57, 331343.

Bharali, R., Tabassum, J. and Azad, M.R. (2003) Chemomodulatory effect of Moringa oleifera, Lam, on hepatic carcinogen metabolising enzymes, antioxidant parameters and skin papillomagenesis in mice. Asian Pac. J. Cancer Prev., 4, 131-139.

Bernardo, A.E.N., Garcia, R.N., Adachi, M., Angeles, J.G.C., Kaga, A., Ishimoto, M., Utsumi, S. and Tecson-Mendoza, E.M.T. (2004). 8S Globulin of mungbean [Vigna radiata (L.) Wilczek]: cloning and characterization of its cDNA isoforms, expression in Escherichia coli, purification, and crystallization of the major recombinant 8S isoform. J. Agric. Food Chemistry, 52, 2552-2560.

Deep, G., Dasgupta T., Rao A.R. and Kale R.K. (2004). Cancer preventive potential of Momordica charantia L. against benzo (a)pyrene induced fore-stomach tumourigenesis in murine model system. Indian J. Exp. Biol., 42, 319-322.

Dia V.P., Garcia, V.V., Mabesa, R.C. and Tecson-Mendoza, E.M. (2005). Comparative physicochemical characteristics of virgin coconut oil produced by different methods. Philipp. Agric. Sci., $88,462-475$.

Eggum, B.O., Alabata, E.P. and Juliano, B.O. (1981). Protein utilization of pigmented and nonpigmented brown and milled rices by rats. Qual. Plant Foods Hum. Nutr., 31, 175-179.

Enig, M.G. (1999). Coconut: In support of good health in the $21^{\text {st }}$ century. Paper presented during the Asian Pacific Coconut Community $30^{\text {th }}$ Anniversary. http: //www.coconutoil.com/ coconut_oil_21st_century.htm

Faizi S., Siddiqui, B.S., Saleem, R., Aftab, K., Shaheen, F. and Gilani, A.H. (1998). Hypotensive constituents from the pods of Moringa oleifera. Plant Med., 6, 225-228.

Garcia, R.N., Adachi, M., Tecson-Mendoza, E.M., Bernardo, A.E.N. and Utsumi, S. (2006). Physicochemical properties of native and recombinant mungbean (Vigna radiata L. Wilczek) 8S globulins and the effects of the N-linked glycans. J. Food Agric. Chem., 54, 6005-6010.

Garcia, V.V., Magpantay, T.O. and Escobin, L.D. (2005). Antioxidant potential of selected Philippine vegetables and fruits. Philipp. Agric. Scientist, 88, 78-83.

Gregorio, G.B., Senadhira, D., Htut H. and Graham, R.D. (2000). Breeding for trace mineral density in rice. Food Nutr. Bull., 21, $382-286$

IFIC (International Food Information Council Foundation) (1998). Backgrounder: Functional foods. In: Food Insight Media Guide. Washington D.C.

ILSI (International Life Sciences Institute) (1999). Safety assessment and potential health benefits of food components based on selected scientific criteria. ILSI North America Technical Committee on Food components for Health Promotion. Crit.
Rev. Food Sci. Nutr., 39, 203-316.

Itoh, T., Garcia, R.N., Adachi, M., Maruyama, Y., Tecson-Mendoza, E.M., Mikami, B. and Utsumi, S. (2006). Crystal structure of $8 \mathrm{~S} \alpha$ globulin, the major seed storage protein of mungbean. Acta Cryst. D, 62, 824-832.

Jagetia, G.C. and Baliga, M.S. (2004).The evaluation of nitric oxide scavenging activity of certain Indian medicinal plants in vitro: a preliminary study. J. Med. Food, 7, 343-348.

Jagetia, G.C. and Venkatesha, V.A. (2005). Effect of mangiferin on radiation-induced micronucleus formation in cultured human peripheral blood lymphocytes. Environ. Mol. Mutagen, 46, 1221.

Juliano, B.O. (2003). Rice Chemistry and Quality. Philippine Rice Research Institute. Nueva Ecija, Philippines, $480 \mathrm{pp}$.

Juliano, B.O. and Bechtel, D.B. (1985). The rice grain and its gross composition. In: "Rice: Chemistry and Technology," $2^{\text {nd }}$ ed, B.O. Juliano, ed. Am Assoc Cereal Chem, St. Paul, MN, USA, pp. 1757.

Kabara, J.J. (1978). Fatty acids and derivatives as antimicrobial agents-A review. In: "The Pharmacological Effect of Lipids" (Kabara JJ, ed) American Oil Chemists Society, Champaign, IL.

Kanazawa, K. and Sakakibara, H. (2000). High content of dopamine, a strong antioxidant in Cavendish banana. J. Agric. Food Chem., 48, 844-848.

Komindr, S., Ingriswang, S., Lerdvuthisopon, N. and Boontawee, A. (2001). Effect of long-term intake of Asian food with different glycemic indices on diabetic control and protein conservation in type 2 diabetic patients. J. Med. Assoc. Thai, 84, 85-97.

Lubag, A.J.M., Laurena, A.C. and Tecson-Mendoza, E.M. (2007). Antioxidants of purple and white greater yam (Dioscorea alata L.) varieties: identification of anthocyanidin alatanin with high antioxidant potential. Submitted for publication.

Mahattanatawee, K., Manthey, J.A., Luzio, G., Talcott, S.T., Goodner, K. and Baldwin, E.A. (2006). Total antioxidant activity and fiber content of select Florida-grown tropical fruits. $J$. Agric. Food Chem., 54, 7355-7363.

Marero, L.M. 2006. A second look at the lowly malunggay. Food and Nutrition Research Institute, Department of Science and Technology. Accessed July 2006. http: //www.fnri@dost.gov.ph

McCue, P. and Shetty, K. (2002). A biochemical analysis of mungbean (Vigna radiata) response to microbial polysaccharides and potential phenolic-enhancing effects for nutraceutical applications. Food Biotechnol., 16, 57-79.

Mendoza, E.M.T., Osawa, T., Nakayama, T., Laurena, A.C. and Kawakishi, S. (1994). Search for new natural antioxidants in selected tropical plant food materials. In: "Postharvest Biochemistry of Plant Food Materials in the Tropics"(Uritani I, Garcia VV, Mendoza EMT, (eds) Japan Scientific Societies Press, Tokyo, Japan, 73-82.

Mendoza, E.M.T., Barroga, C.F., Rodriguez, F.M., Revilleza, M.J.R. and Laurena, A.C. (1988). Factors affecting the nutritional quality and acceptability of mungbean [Vigna radiata (L.) Wilzeck]. Trans. Natl. Acad. Sci. \& Tech. (Phil.), 10, 305-322.

Moldenhauer, K.A., Champagne, E.T., McCaskill, D.R., and Guraya, H. (1998). Functional products from rice. In: "Functional Foods: Biochemical and Processing Aspects" Vol. 1. G Mazzo, ed, Technomic Publ. Co. Inc, Lancaster, PA, USA, pp. 71-89.

Mohan Kumar, M., Joshi, M.C., Prabha, T., Dorababu, M. and Goel, R.K. (2006). Effect of plantain banana on gastric ulceration in NIDDM rats: role of gastric mucosal glycoproteins, cell proliferation, antioxidants and free radicals. Indian J. Exp. Biol., 44, 292-299.

Murcia, M.A., Jimenez, A.M. and Martinez-Tome, M. (2001). Evaluation of the antioxidant properties of Mediterranean and tropical fruits compared with common food additives. J. Food Prot., 64, 2037-2046.

Nevin, K.G. and Rajamohan, T. (2004). Beneficial effects of virgin 
coconut oil on lipid parameters and in vitro LDL oxidation. Clin. Biochem., 37, 830-835.

Obanni, M., Mitchell, C. and Medcalf, D. (1998). Healthy ingredients and foods from rice. Agric. Biol. Chem., 29, 191-195.

Osato, J.A., Korkina, L.G., Santiago, L.A. and Afanas'ev I.B. (1995). Effects of bio-normalizer (a food supplementation) on free radical production by human blood neutrophils, erythrocytes, and rat peritoneal macrophages. Nutrition 11(5Suppl), 569-572.

Osato, J.A., Santiago, L.A., Remo, G.M., Cuadra, M.S. and Mori, A. (1993). Antimicrobial and antioxidant activities of unripe papaya. Life Sci., 53, 1383-1389.

Percival, S.S., Talcott, S.T., Chin, S.T., Mallak, A.C., LoundsSingleton, A. and Pettit-Moore J. (2006). Neoplastic transformation of BALB/3T3 cells and cell cycle of HL-60 cells are inhibited by mango (Mangifera indica L.) juice and mango juice extracts. J. Nutr., 136, 1300-1304.

Philippine Daily Inquirer (PDI). (2005). Virgin coconut oil exports surge. November 15, 2005.

Prabhu, S., Jainu, M., Sabitha, K.E. and Devi, C.S. (2006). Role of manginferin on biochemical alterations and antioxidant status in isoproterenol-induced myocardial infarction in rats. $J$. Ethnopharmacol., 107, 126-133.

Prudente, V.R. and Mabesa, L.B. (1984). Vitamin content of mungbean [Vigna radiata (L.) Wilzeck] sprouts. Philipp. Agr., 64, 365370.

Randhir, R., Lin, Y.-T. and Shetty, K. (2004). Stimulation of phenolics, antioxidant and antimicrobial activities in dark germinatied mungbean (Vigna radiata) sprouts in response to peptide and phytochemical elicitors. Process. Biochem., 39, 637-646.

Salil, G., and Rajamohan, T. (2001). Hypolipidemic and antiperoxidative effect of coconut protein in hypercholestrolemic rats. Indian J. Exp. Biol., 39, 1028-34.

Santiago, L.A., Osato, J.A., Liu, J. and Mori, A. (1993). Age-related increases in superoxide dismutase activity and thiobarbituric acid-reactive substances: effect of bio-catalyzer in aged rat brain. Neurochem. Res., 18, 711-717.

Sathishsekar, D. and Subramanian, S. (2005). Antioxidant pro- perties of Momordica charantia (bitter gourd) seeds on Streptozotocin induced diabetic rats. Asia Pac. J. Clin. Nutr., 14, 153158.

Smith-Schneider, S., Roberts, L.A. and Shetty, K. (2006). Phytochemicals and breast cancer chemoprevention. In: "Functional Foods and Biotechnology" Shetty, K., Paliyath, G., Pometto, A.L., Levin, R.E. (eds). CRC Taylor \& Francis, 253-289.

Sun, J., Chu, Y.F., Wu, X. and Liu, R.H. (2002). Antioxidant and antiproliferative activities of common fruits. J. Agric. Food Chem., 50, 7449-7454.

Tecson-Mendoza, E.M., Rodriguez, F.M., Revilleza, M.J.R. and Laurena, A.C. (2003). Biochemistry of Philippine Indigenous Legumes. National Academy of Science and Technology Philippines, Manila, Philippines, 106 pp.

Tecson-Mendoza, E.M., Adachi, M., Bernardo, A.E.N. and S. Utsumi. (2001). Mungbean (Vigna radiata (L.) Wilczek) globulins: Purification and characterization. J. Agric. Food Chemistry, 49, 15521558.

Trinidad, T.P. (2005). Dietary fiber in coconut flour, local root crops and legumes as promising functional foods. Paper presented during the "Symposium on the Development Prospects of Functional Foods in the Philippines: Research and Regulatory Issues" held in Makati City, Philippines, February 6, 2004. Manila, Philippines.

Trinidad, T.P., Valdez, D.H., Loyola, A.S., Mallillin, A.C., Askali, F. C., Castillo, J.C. and Basa, D.B. (2003). Glycaemic index of different coconut (Cocos nucifera)-flour products in normal and diabetic subjects. British J Nutr., 90, 551-556.

Trinidad T.P., Loyola, A.S., Mallillin, A.C., Valdez, D.H., Askali, F. C., Castillo, J.C., Resaba, R.L. and Basa, D.B. (2004). The cholesterol-lowering effect of coconut flakes in humans with moderately raised serum cholesterol. J. Med. Food, 7, 136-140.

USDA (United States Department of Agriculture). (2005). USDA National Nutrient Database for Standard Reference, Release 18. http : / / www.nal.usda.gov.fnic/foodcomp / search/index. html (Accessed August 2006) 